NBER WORKING PAPER SERIES

\title{
DOES GLOBALIZATION OF THE SCIENTIFIC/ENGINEERING WORKFORCE THREATEN U.S. ECONOMIC LEADERSHIP?
}

\author{
Richard B. Freeman \\ Working Paper 11457 \\ http://www.nber.org/papers/w11457 \\ NATIONAL BUREAU OF ECONOMIC RESEARCH \\ 1050 Massachusetts Avenue \\ Cambridge, MA 02138 \\ June 2005
}

The views expressed herein are those of the author(s) and do not necessarily reflect the views of the National Bureau of Economic Research.

(C)2005 by Richard B. Freeman. All rights reserved. Short sections of text, not to exceed two paragraphs, may be quoted without explicit permission provided that full credit, including (C) notice, is given to the source. 
Does Globalization of the Scientific/Engineering Workforce Threaten U.S. Economic Leadership?

Richard B. Freeman

NBER Working Paper No. 11457

June 2005

JEL No. G0, I2, F0, J0

\section{ABSTRACT}

This paper develops four propositions that show that changes in the global job market for science and engineering (S\&E) workers are eroding US dominance in S\&E, which diminishes comparative advantage in high tech production and creates problems for American industry and workers:

(1) The U.S. share of the world's science and engineering graduates is declining rapidly as European and Asian universities, particularly from China, have increased S\&E degrees while US degree production has stagnated.

2) The job market has worsened for young workers in S\&E fields relative to many other high-level occupations, which discourages US students from going on in S\&E, but which still has sufficient rewards to attract large immigrant flows, particularly from developing countries.

3) Populous low income countries such as China and India can compete with the US in high tech by having many S\&E specialists although those workers are a small proportion of their work forces. This threatens to undo the "North-South" pattern of trade in which advanced countries dominate high tech while developing countries specialize in less skilled manufacturing.

4) Diminished comparative advantage in high-tech will create a long period of adjustment for US workers, of which the off-shoring of IT jobs to India, growth of high-tech production in China, and multinational R\&D facilities in developing countries, are harbingers.

To ease the adjustment to a less dominant position in science and engineering, the US will have to develop new labor market and R\&D policies that build on existing strengths and develop new ways of benefitting from scientific and technological advances in other countries.

Richard B. Freeman

National Bureau Economic Research

1050 Massachusetts Avenue

Cambridge, MA 02138-5398

freeman@nber.org 
For the past half century the US has been the world scientific and technological leader and the pre-eminent market economy. With just 5\% of the world's population, the US employs nearly one-third of the world's scientific and engineering researchers, accounts for $40 \%$ of research and development (R\&D) spending, publishes $35 \%$ of science and engineering (S\&E) articles, obtains $44 \%$ of S\&E citations, and wins numerous Nobel prizes. ${ }^{1}$ Seventeen of the world's top 20 universities are American. ${ }^{2}$ Indicative of US leadership, international students and scholars flock to the country to enhance their skills and collaborate with American researchers.

Leadership in science and technology gives the US its comparative advantage in the global economy. US exports are disproportionately from sectors that rely extensively on scientific and engineering workers and that embody the newest technologies. In 2003, with a massive national trade deficit, the smallest deficit relative to output was in high technology industries. Aggregate measures of scientific and technological prowess place the US at the top of global rankings. ${ }^{3}$

Trade aside, the US is the leading capitalist economy because it applies new knowledge in more sectors than any other economy. Many companies on the technological frontier are American multinationals: IBM, Microsoft, Intel, Dupont, and so on. Analysts attribute the country's rapid productivity growth in the 1990 s/2000s to the adaption of new information and communication technologies to production. Scientific and technological preeminence is also critical to the nation's defense, as evidenced by the employment of R\&D scientists and engineers in defense related activities and in the technological dominance of the US military on battlefields. To be sure, other factors also contribute to US economic leadership, ${ }^{4}$ but in a knowledge-based economy, leadership in science and technology contributes substantially to economic success.

This paper presents evidence that changes in the global job market for S\&E workers is eroding US dominance in science and engineering and that the erosion will continue into the 
foreseeable future, diminishing the country's comparative advantage in high tech goods and services and threatening the country's global economic leadership. The paper assesses policies that could smooth the transition from the US being the superpower in science and engineering to being one of many centers of excellence.

The analysis can be summarized in four propositions, two relating to the job market for scientific and engineering talent, and two relating to the effects of that market on the economy.

The propositions regarding the science and engineering (S\&E ) job market are:

(1) The U.S. share of the world's science and engineering graduates at all degree levels is declining rapidly, as college enrollments have expanded in other countries. The number of S\&E PhDs from European and Asian universities, particularly from China, has increased while the number from US universities has stagnated. International students have, in addition, increased their share of advanced S\&E degrees from US universities. As a result US reliance on foreignborn scientists and engineers has increased.

2) The job market for young scientists and engineers in the US has worsened relative to job markets for young workers in many other high-level occupations, which discourages US students from going on in these fields. At the same time, rewards are sufficient to attract large immigrant flows, particularly from less developed countries.

The propositions regarding the impact of changes in the supply of science and engineering talent on the country's economic performance are:

3) By increasing the number of scientists and engineers, highly populous low income countries such as China and India can compete with the US in technically advanced industries even though S\&E workers are a small proportion of their work forces. This threatens to undo the traditional "North-South" pattern of trade in which advanced countries dominate high tech while 
developing countries specialize in less skilled manufacturing.

4. Diminished comparative advantage in high-tech will create adjustment problems for US workers, of which the offshoring of IT jobs to India, growth of high-tech production and exports from China, and multinational movement of R\&D facilities to developing countries, are harbingers. The country faces a long transition to a less dominant position in science and engineering associated industries, for which the US will have to develop new labor market and R\&D policies that build on existing strengths and develop new ways of benefitting from scientific and technological advances in other countries.

The rest of the paper presents the evidence and arguments for the four propositions and examines the implications for policy.

\section{Proposition 1: The US's share of the world's S\&E work force is declining rapidly.}

The US share of the world's S\&E workers was disproportionately high in the latter half of the $20^{\text {th }}$ century for historical reasons that include: the flight of many leading European scientists from the Nazis; the slow post-World War II recovery of higher education and science in Europe, which had dominated science before the War; the rapid expansion of mass college education in the U.S. in the 1950s and 1960s; increased US spending on R\&D and doctorate S\&E education in response to Sputnik; the concentration of Soviet science and engineering on military technology; and the destructive effects of the cultural revolution on education in China. In 1970 US predominance was such that the country enrolled approximately $30 \%$ of tertiary level students in the world. Over half of science and engineering doctorates were granted by US institutions of higher education.

Since then the rest of the world has begun to catch up with the US in higher education and in educating S\&E specialists in particular. The number of young persons going to college has 
increased rapidly in other OECD countries and in many less developed countries, particularly China. Enrollments in college or university per person aged 20-24 and/or the ratio of degrees granted per 24 year old and in several OECD countries (Australia, New Zealand, Netherlands, Norway, Finland, the United Kingdom, and France) exceeded that in the US. ${ }^{5}$ In 2001-2002, UNCESCO data show that the US enrolled just $14 \%$ of tertiary level students - less than half the US share 30 years earlier. ${ }^{6}$ In most countries, moreover, a larger proportion of college students studied science and engineering than in the US, so that the US share of students in those fields was considerably lower than the US share overall. In $2000,17 \%$ of all university bachelor's degrees in the US were in the natural sciences and engineering compared to a world average of $27 \%$ of degrees, and to $52 \%$ of degrees in China. ${ }^{7}$

At the graduate level, the $\mathrm{PhD}$ is the critical degree in science, particularly for advanced research activities. Exhibit 1 records the ratios of $\mathrm{PhDs}$ earned in science and engineering in major $\mathrm{PhD}$ producing countries relative to the numbers granted in the US from 1975 to 2001 and extrapolates the numbers to 2010. PhDs in science and engineering outside the US rise sharply whereas the number granted in the U.S. stabilizes at about 18,000 per year. In 2001 the EU granted 40\% more S\&E PhDs than the U.S. Trend data suggest that the EU will produce nearly twice as many S\&E doctorates as the U.S. by 2010 or so.

But the greatest growth is in China. In 1975 China produced almost no S\&E doctorates. In 2003, the country graduated $13,000 \mathrm{PhDs}$, approximately $70 \%$ in science and engineering. Between 1995 and 2003, first year entrants in PhD programs in China increased six-fold, from 8,139 to 48,740 . At this rate China will produce more S\&E doctorates than the U.S. by 2010 ! The quality of doctorate education surely suffers from such expansion, so the numbers should be discounted to some extent, but as the new doctorate programs develop, the discount factor will 
decline.

Overall, the U.S. share of world S\&E PhDs will fall to about $15 \%$ by 2010 . Within the US, moreover, international students have come to earn an increasing proportion of S\&E PhDs. In 1966, US-born males accounted for $71 \%$ of science and engineering $\mathrm{PhDs}$ awarded; $6 \%$ were awarded to US-born females; and 23\% were awarded to the foreign-born. In 2000, 36\% of S\&E PhDs went to U.S.-born males, $25 \%$ to U.S.-born females and $39 \%$ to the foreign-born. ${ }^{8}$ Looking among the S\&E fields, in 2002, international students received $19.5 \%$ of all doctorates awarded in the social and behavioral sciences, $18.0 \%$ in the life sciences, $35.4 \%$ in the physical sciences, and 58.7\% in engineering. ${ }^{9}$ Since few US students earn S\&E PhDs overseas, moreover, the ratio of S\&E PhDs earned by US citizens or residents to those earned by citizens of other countries fell more rapidly than the ratio of degrees granted by US universities to degrees granted by foreign universities. $^{10}$

Finally, the foreign-born share of science and engineering degrees earned in the US is also substantial for master's and bachelor's graduates. For physics, $6 \%$ of bachelor's degrees, $40 \%$ of master's degrees, and $42 \%$ of $\mathrm{PhD}$ degrees went to foreign-born students in $2003 .{ }^{11}$ Among engineers, $42 \%$ of master's degrees and $49 \%$ of graduate students (most of whom are non-PhD students) were foreign-born/held temporary visas in 2001/2002. ${ }^{12}$ The US share of world bachelor's engineering degrees granted - the key degree in engineering - dropped in half in the 1990 s -- from approximately $12 \%$ in 1991 to $6 \%$ in $2000 .^{13}$

\section{employment}

The US recruits its graduate S\&E work force from three sources: US-born residents who choose S\&E careers, international students who stay in the country after earning US degrees; and scientists and engineers who earn degrees overseas and immigrate to the country. ${ }^{14}$ Exhibit 2 
records the number employed in science and engineering occupations from the 1990 and 2000 Censuses of Population and in the 2004 Current Population Survey (CPS), Merged Outgoing Rotation group files. The Census data show that in 2000 , the foreign-born made up $17 \%$ of bachelor's S\&E workers, $29 \%$ of master's S\&E workers, and $38 \%$ of the PhD S\&E workforce huge increases over the comparable proportions in 1990. Indicative of the future, the foreign-born made up over half of doctorate scientists and engineers under the age of 45 in 2000 and approximately $60 \%$ of post-doctorate workers. Nearly $60 \%$ of the growth in the number of $\mathrm{PhD}$ scientists and engineers in the country in the 1990s came from the foreign born. The CPS data show comparable percentages of foreign-born for bachelor's and doctorate degree employees, but a higher proportion of the foreign born among master's degree recipients.

Since neither the CPS nor the Census ask where someone earned their degree, these data do not distinguish between international students who chose to stay in the US and immigrants who come with foreign degrees. At the doctorate level, the Survey of Earned Doctorates shows that many international students intend to remain in the US to work after they graduate. This is particularly true for students from developing countries, where earnings are lower and scientific facilities are not at US level. Micheal Finn has estimated that in the $2001 \mathrm{PhD}$ graduates cohort, $71 \%$ of foreign-born doctorates remained in the United States for at least 2 years. This compares to an estimated stay rate of $49 \%$ for the 1989 cohort. PhDs from China are especially likely to remain in the country. ${ }^{15}$

But immigrants with foreign degrees are also quite important. The 2000 Census reported a much higher number of foreign-born S\&E workers than did the NSF's SESTAT data system, ${ }^{16}$ because the latter counts foreign-born recipients of US degrees but not immigrants with overseas degrees between Censal years. ${ }^{17}$ Among post doctorate workers, who are a critical input in nearly 
all laboratories, about four-fifths of academic postdoctoral scholars holding temporary visas have non-US doctorates and around half of all academic postdoctoral scholars have non-US

doctorates. ${ }^{18}$ Finally, indicative of the growing reliance on the foreign born, NSF data show that foreign-born faculty who earned their doctoral degrees at US universities increased in number from $12 \%$ in 1973 to $20 \%$ in 1999 . In engineering fields they increased from $18.6 \%$ to $34.7 \%$ in the same period. ${ }^{19}$

\section{trade-offs in supplies}

Because changes in the supply from one source affects the total number of S\&E workers in the market, those changes necessarily impacts earnings and employment opportunities (Freeman, 1971, 1975, 1976; Borjas, 2003). An increase in the supply of immigrant S\&E workers will, all else the same, reduce earnings and employment opportunities below what they otherwise would have been, thus lowering the incentives for persons from that and from other sources to enter the S\&E job market. The supply of US born/residents, particularly men, to science and engineering appears to be more responsive to labor market conditions than the supply of the foreign born. This reflects the fact that US born have access to other careers in the country, whereas science and engineering careers may be the only way for many talented foreign-born persons to enter the US job market. The ability to recruit international students and immigrant scientists and engineers for the US S\&E job market benefits the country by tapping a large and relatively inexpensive pool of talent at the cost of reduced incentives for native-born individuals to go on in science and engineering.

Trends in demography and in $\mathrm{PhD}$ production rates outside the US will reduce the U.S. share of S\&E graduates at all degree levels. Assuming comparable training and ability around the world, US firms and universities who seek the most talented people will increase the foreign born 
share of their work forces in the future. But even with a sizable immigration of foreign-born talent to the country, the demographic forces will invariably reduce the share of science and engineering specialists working in the US, which should reduce the country's dominance of science and technology.

Data on publications and citations by country of investigator show that the US predominance has already begun to drop in many areas. In spring 2004, the front page of The New York Times reported a fall in the U.S. share of papers in physics journals while Nature reported a rise in the share of papers in China. ${ }^{20}$ The NSF records a drop in the US share of scientific papers from $38 \%$ in 1988 to $31 \%$ in 2001 and a drop in the US share of citations from 52 percent in 1992 to 44 percent. $^{21}$ The share of papers counted in the Chemical Abstract Service fell from $73 \%$ in 1980 to $40 \%$ in $2003 .^{22}$ While attention has focused on the increased scientific capability of China, ${ }^{23}$ Latin American countries have also increased their share of science publications. ${ }^{24}$ One aspect of the fall in the US share that has attracted attention is that it has been associated with a decline in publications in some disciplines from US-based scientists and engineers (Hicks, 2004). As the US share of the world's S\&E specialists falls, it is inevitable that the US share of papers will fall, but there is no reason for numbers of papers to fall, given the increased numbers of journals. $^{25}$

Similarly, as the supply of S\&E graduates has increased overseas, many high-tech companies have begun to locate major research installations outside the U.S. In 2004, the CEO of Cisco declared that "Cisco is a Chinese company" when he announced that the firm was setting up its newest R\&D facility in China. ${ }^{26}$ One of Microsoft' $s$ major research facilities is in Beijing. OECD data shows a large increase in U.S. outward R\&D investment from 1994 to 2000. A 2004 survey of corporate executives by the Intelligence Unit of The Economist found that the five top 
countries in which firms intended to increase R\&D outside of their home country were China, the U.S., India, the UK, and Germany. The three most critically important factors cited by executives when selecting R\&D locales were "local R\&D expertise in your industry," followed by "availability of R\&D scientists with appropriate skills," and "cost of labour of R\&D.",27 As of mid 2004, the Chinese government registered over 600 multinational research facilities in the country, many from large US multinationals. ${ }^{28}$ By contrast, in 1997 China registered less than 50 multinational corporation research centers.

Proposition 2: Despite perennial concerns over shortages of scientific and engineering specialists, the job market in most $\mathrm{S} \& \mathrm{E}$ specialties is too weak to attract increasing numbers of US students.

Every few years or so, the scientific establishment and/or the top executives from major high technology firms proclaim that the US has a shortage of S\&E workers and call for diverse policies to attract more Americans into the fields and/or to make it easier to bring foreign $\mathrm{S} \& \mathrm{E}$ workers into the country.

Economists have struggled to interpret claims that the U.S. had a shortage of scientific and engineering workers since the 1950s, when such claims first surfaced. In any market-clearing transaction where wages equilibrate demand and supply, there can no "shortage" or "surplus." There is disappointment about the price, either by suppliers (when a "surplus" reduces prices) or by demanders (when a "shortage" raises price), that can generate longer run responses in the form of investment to increase the supply or substitution of alternative inputs for the high-priced input. Arrow and Capron interpreted shortages as the result of sluggish wage adjustments. Stigler interpreted them as reflecting rapid changes in wages. Freeman stressed the cyclic nature of shortages and surpluses in the context of a cobweb model of market adjustment.

Wages are not, however, the only equilibrating force or indicator of the state of the labor 
market. In the market for researchers, the duration of postdoctoral work before obtaining a fulltime job, the probability of getting an independent research grant, or of landing a tenure track job at an institution of given quality, etc, are also important mechanisms for market adjustment. In a loose labor market, young persons are likely to spend more years as post-docs at low postdoctorate pay than in a tight labor market. In 1993 the American Institute of Physics proclaimed "The Physics Job Market: From Bear to Bull in a Decade: What a difference 8 years makes" and used a graph that showed fewer new physics doctorates taking post-docs and more getting jobs to make its point. ${ }^{29} \mathrm{New}$ PhDs pay close attention to the quality of academic institutions making job offers. In a tight market, graduates end up in highly esteemed labs or universities. In loose markets, they accept jobs in places judged as lower quality.

Whichever indicator one examines, the evidence suggests that the job market for most scientists and engineers in the US has fallen short of the job markets in competitive high level occupations. Exhibit 3 records levels of pay and rates of change in pay from the Census of Population. It shows that scientists and engineers earn less than law and medical school graduate, and that rates of increase in earnings for science and engineering in the 1990's fell short of the rates of increase for doctors and lawyers and for persons with bachelor's degrees.

The Census comparisons of the income between S\&E doctorates and persons obtaining medical or law professional degrees understate the lower income associated with the $\mathrm{PhD}$ trajectory. Doctoral graduate students typically spend 7-8 years earning their $\mathrm{PhD}-$ a quarter of their post-bachelors working life - during which they are paid stipend rates. In some disciplines, notably the life sciences, most spend 3 or so years doing postdoctoral work, again at stipend incomes that fall far below alternative salaries available to bachelors degree holders or those with professional degrees. Since postdocs work many hours, their pay is particularly low on an hourly 
basis for someone with their years of education. Given their lengthy training and post-doctoral work, many S\&E doctorates do not enter the "real job market" until they are in their mid-30s, by which time many of their undergraduate classmates who chose other careers are well-established in their work lives. The comparison with managers with 2 years of post-bachelor's training does not adequately reflect the payoff to MBAs since the post-bachelor's education refers to any sort of further education, not to that degree.

The differences in the percentage changes in salaries in exhibit 3 show that the doctorate fields have had smaller gains in salaries than the professional fields and persons with only bachelor's training, though the increases are similar or larger than those for the managers with two years post-baccalaureate schooling, depending on the $\mathrm{PhD}$ field. Smaller increases in pay for doctorates in general imply that the market for PhDs was falling behind the markets for other groups of highly educated workers.

Combining the pay differences between doctorate scientists and engineers and highly educated workers in other fields together with the difference in years of education and postdoctorate training produces huge differences in lifetime earnings. Translating Census of Population earnings by age group, per the data in exhibit 3, into lifetime incomes, discounted at $5 \%$, biological scientists had lifetime earning on the order of $\$ 3$ million dollars less over their lifetime than doctors and 1.8 million dollars less than lawyers. Doctors and lawyers pay for their education, while $\mathrm{PhD}$ scientists receive fellowships or stipends and rarely pay tuition, though they often work for their fellowship support, but this hardly equates the lifetime earnings. Physicists and mathematicians had higher discounted lifetime earnings than biological scientists, while engineers had the highest earnings among $\mathrm{PhDs}$, but even those earnings fall considerably short of the earnings of doctors. 
Looking beyond salaries, the demographics of the academic job market made it increasingly difficult for doctorate graduates to obtain faculty jobs even as older scientists retire. In 1973 , roughly $73 \%$ of new $\mathrm{PhDs}$ obtained faculty jobs within three years of earning their degrees. By 1999, just 37\% of new PhDs obtained faculty jobs within three years of earning their degrees. To see how the demographics of the job market operates to determine the probability of academic employment in the life sciences, I have developed a quantity adjustment model of demand and supply for new faculty, in which the proportion of post-docs obtaining academic jobs rather than salary is the chief adjustment mechanism. The demand side of the model defines the number of persons employed as faculty as the sum of demand for replacements for retiring faculty plus demand from growth of faculty, which occurs at $\mathrm{r} \%$ per year. I assume steady state so that the retirement of existing faculty $\mathrm{F}$ is just 1/length of time of an academic career, which I take to be 30 years. Thus annual demand for new academics is

(1) $\mathrm{F} / 30+.0 \mathrm{r} \mathrm{F}$

On the supply side, there are PD postdoctoral recipients, with postdoctoral awards that last 3 years, so the supply of post-docs to the academic job market is $\mathrm{PD} / 3$. In the steady state one-third of post-docs will complete their three year award and enter the job market. Letting $b$ measure the proportion of post-docs who obtain academic jobs, the supply of new academics is:

(2) $\mathrm{bPD} / 3$

Setting $(1)=(2)$, the market clearing proportion of post-docs who obtain academic jobs is:

(3) $b=F /(10 \mathrm{PD})+3(.0 \mathrm{r}) \mathrm{F} / \mathrm{PD}=(1 / 10+.0 \mathrm{r}) \mathrm{F} / \mathrm{PD}$.

Exhibit 4 shows that the ratio of postdoctoral students to tenured faculty rose greatly from 1987 to 1999 to reach 0.77 , which gives a ratio of F/PD of 1.30 . This implies that if faculty jobs were unchanged $(r=0)$, just $13 \%$ of post-docs would find faculty positions (1.30/10). Even if the 
number of faculty jobs increased at $5 \%$ per year, just $20 \%$ of the post-docs would find faculty jobs. The implication is clear: a much smaller proportion of life science post-docs will move into academic jobs in the future than in the past. Universities and principal investigators therefore have a responsibility to prepare life science $\mathrm{PhDs}$ and post-docs for jobs outside of the standard academic track. Since post-docs are less common and the ratio of post-docs to faculty much smaller outside of the biological sciences, the potential for obtaining academic jobs is much higher. Still, the model identifies the factors that will determine the academic market in those fields as well - the rate of growth of new demand, retirements, and the ratio of graduates to faculty.

Finally, because NIH grants are awarded to faculty members rather than to post doctorate scientists, the probability that young scientists obtain grants to work as independent investigators has fallen to negligible numbers. Exhibit 5 uses NIH data on the age distribution of recipients of R01 grants, and the age distribution of doctorate life scientists to show how the chances young investigators would get their own grants fell sharply in the past 20 or so years. These data show that the proportion given to scientists less than 35 years old fell from $20 \%$ in 1980 to $4 \%$ in 2002 whereas the proportion of grants going to scientists aged 45 years and older rose from $22 \%$ to $60 \%$. Dividing these proportions by the proportion of doctorates in the relevant age brackets gives the relative odds of obtaining an R01 grant. ${ }^{30}$ The relative odds drop from 1.21 to 0.30 for scientists less than 35 years old. In 1980 they had a greater chance of getting an award than older scientists, whereas in 2002 they had a much smaller chance. The relative odds rises for the oldest age group of scientists.

\section{job market for bachelor's and master's graduates}

Is there any evidence of shortages in the job market for bachelor's or master's graduates in 
science and engineering?

The BS in engineering is the key terminal bachelor's degree for scientists and engineers. S\&E employment in industry consists largely of bachelor's engineering graduates. Since the end of world war II, the job market for engineers has shown cyclic oscillations of the cobweb variety. (Freeman, 1971, 1975, 1976). Exhibit 6 shows the variation in numbers enrolled as first year engineering students from 1946 to 2001 . Tight labor markets generate large increases in supply that depress the labor market approximately 4-5 years later. Similar patterns are observed in other fields. Starting salaries show that engineers make more than other bachelor's graduates, with however marked differences among specialties depending on how the industries that typically hire a given specialty are doing and the number of graduates. Cycles aside, the proportion of the work force in engineering has trended upward, from $0.9 \%$ of the work force in 1950 to $1.8 \%$ in $2003 .^{31}$ Engineering is the largest S\&E occupation, by far.

Scientists and engineers traditionally have low rates of unemployment and reasonably secure job prospects. But in 2003 the unemployment rate for U.S. electrical and electronics engineers (Ees) rose to a record 6.2 percent, which exceeded the average unemployment rate for all workers of 5.6 percent in that year. ${ }^{32}$ The 2003 jobless rate for computer scientists and systems analysts also reached an all-time high of 5.2 percent. Both unemployment rates fell thereafter, though not to historically low levels. Since many engineers who lose jobs are likely to find other work relatively quickly - outside the field and probably at reduced earnings - the unemployment rate understates the weakness and risk involved in the job market for some specialties. A more striking indication of the weakness and risk in this job market is that between 2000 and 2002 the Bureau of Labor Statistics reduced its projections of the growth rate for employment of computer specialists (and mathematical scientists, a much smaller group) by one half. ${ }^{33}$ It projects about a 
million fewer jobs in this area in the next decade than it had previously. The reason appears to be the growth in off-shoring computer work. This change in market prospects highlights the riskiness of S\&E work in a global economy where other countries are producing many highly skilled substitutes for U.S. workers.

Exhibit 2 showed a huge flow of immigrant scientists and engineers with less than doctorate degrees. Some of this flow occurred as a result of the issuance of H1-B visas during the dot.com boom, when many high-tech firms complained about labor market shortages. But most was generated by normal immigration patterns. Given much larger numbers of engineering graduates in foreign countries, with huge increases in graduates in India and China, the pool of potential foreign-born engineers is certain to increase. Although only a minority of these graduates are likely to be suitable for the work performed by major multinational firms, even a modest proportion of the increased supply will give more firms the choice between hiring immigrant engineers and scientists in their US facilities or hiring foreign-born specialists in their own countries.

If the labor market measures show that the job market for scientists and engineers has been relatively weak, what explains the large influx of international students and scientists and engineers from overseas into the country?

One reason that foreign born students and degree recipients are attracted to science and engineering work in the US while many US citizens or permanent residents do not find that work attractive is that the foreign-born have lower opportunity costs from other specialties than do Americans. The higher average incomes in the US, particularly compared to developing countries, and the greater dispersion of earnings in the US, particularly compared to other high income countries, means that US students, particularly the most able, have more lucrative non-S\&E 
options than do foreign-born students. To many foreign-born students or workers, obtaining an S\&E education or job is their ticket to the US job market, a green card, and possible citizenship. Their opportunities in their native country outside of science and engineering are far less attractive than are the opportunities outside of science and engineering to comparable Americans.

Even the 1995-2004 doubling of the R and D budget for NIH did not improve the wellbeing of new investigators enough to attract as many US students as foreign students into postdoctorate positions in the bio/medical sciences. From 1995 to 2002, the number of Americans accepting postdoctoral positions in the biological sciences barely changed while the number of foreign-born PhDs accepting postdoctoral appointments in the biological sciences increased. In medical and other life sciences (which the NSF data differentiate from biological sciences), the number of citizens/permanent residents accepting post-docs increased modestly while the number of foreign-born post-docs grew by over $50 \%$ As a result, the foreign-born share of postdoctoral appointments in biological science and medical/other life sciences rose from $48.0 \%$ (1995) to $54.7 \%(2002){ }^{34}$ At NIH itself - the largest single employer of scientists in bio-medical research $46 \%$ of the doctoral level staff were foreign-born and $58 \%$ of the postdoctoral workers were foreign-born as of October, 2004. And a substantial number of U.S. passport holders at the doctoral staff level at NIH were themselves naturalized immigrants. ${ }^{35}$

\section{Women and minorities}

While proportionately fewer US men have chosen science and engineering careers, more women and under represented minorities have chosen to major in science and engineering as undergraduates and to go on to master's and doctorate degrees. As a result the proportion of bachelor's, masters, and doctorates degrees awarded to women and minorities in science and engineering fields has trended upward from the 1970s through the early 2000s, albeit at different 
rates in different fields (Chang, Chiang, Freeman). In 2004, women won 55\% of National Science Foundation Graduate Research Fellowships. The increased numbers of women earning science and engineering doctorates is due more to increases in the numbers of women obtaining bachelor's degrees in these fields than to increases in the propensity of female bachelor's graduates to go on to PhDs. With women earning 57\% of all bachelor's degrees in the early 2000s and making up $63 \%$ of US persons taking the Graduate Record Exam, the proportion of women with science and engineering degrees is likely to continue to rise. Universities and other employers will have to find ways to make careers in scientific work more consistent with women's role in family life, particularly child-bearing and child-rearing, if the country is going to use this new source of talent optimally.

The increase in the number of under represented minority groups going on in science and engineering is substantial as well. In 1976 blacks and Hispanics earned barely 2\% of S\&E PhDs granted to US citizens or residents, whereas in 2001 they earned nearly $10 \%$ of S\&E PhDs granted to US citizens or residents (Chang, Chiang, Freeman).

Why have women and minorities chosen to enter science and engineering whereas white men have shifted to other fields?

There are two possible explanations. The first is that the proportions of women and minorities in science and engineering in the past was low because S\&E did not readily welcome them - implicit or explicit discrimination. The supply of women and minorities was constrained or discouraged. The increased proportions are thus a movement toward a new equilibrium that more properly reflects interests and talents. The second is that the opportunity cost for women and minorities is lower due to less attractive opportunities in other high level occupations. For women, the large increase in the numbers in medical and law schools argues against this factor being as 
important as the national effort to equalize opportunities and increase diversity in S\&E fields. Whatever the particular causes, it is striking that without an overall improvement in the overall S\&E job market, more women and minorities have obtained S\&E degrees and entered S\&E occupations.

\section{Reconciling the data and the shortage claims}

Since labor market measures show no evidence of shortages of S\&E workers, is there any way to make sense of continued claims that the US has a shortage of scientists and engineers and of calls for more young Americans to enter these fields rather than others? How can there be a shortage which does not show up in the job market - a shortage that is not a shortage?

One interpretation of the continual claims of a shortage is that they are disingenuous. Firms benefit from a greater supply of scientists and engineers at given wage rates, or better yet, at lower wage rates. H1-B visas allowed firms to hire trained specialists without the pay rises that would be necessary to attract more US workers. Foreign-born students and post-docs allow principal investigators to produce research at relatively low cost. The greater the supply of postdocs at current pay, the more cost-effective is US research spending. In the 1980s, NSF forecast shortages of scientists and engineers with the seeming goal of increasing supplies so that US firms could hire scientists and engineers at lower wages. Congressional Hearings, which highlighted these forecasts, produced editorials in $\underline{\text { Science }}$ and Nature, and an apology from NSF that has made all analysts dubious of shortage claims (Weinstein).

A second interpretation, which I think more accurately captures current concerns, is that the US has an adequate supply of scientists and engineers only because of the sizeable influx of foreign-born students and employees. If US economic growth and comparative advantage depend substantially on the work of scientific and engineering workers, relying so much on foreign born 
supplies could be risky. Any interruption or change in the flow of immigrant scientists and engineers would certainly harm US research and development. Imagine NIH without foreign-born post-docs and scientists. Imagine the labs at any major university or high tech firm without foreign-born students. Half of the benches would be empty. From this perspective, the call for more US students to go into science and engineering reflects a belief that the balance between the supply of US born and of foreign-born scientists and engineers may have tilted too much toward the latter. It is not a shortage of scientists and engineers but of US entrants into the field. But many of the persons and firms who make these arguments do not face up to the potential trade-off issue: that to attract more US citizens, earnings and employment opportunities have to get better, which is difficult to effectuate as long as the country can attract many scientists and engineers from overseas at current wages and employment opportunities..

\section{Proposition 3: Technological Edge and Global Competition When Numbers Count}

Trade models designed to explain the extensive trade among advanced countries with similar factor endowments posit that the trade occurs because countries gain advantages from being the first-mover on new technologies, which require R\&D resources, and/or from increasing returns, say through learning as output increases or through positive spillovers from one firm in a sector to another. In these models countries make their comparative advantage by investment decisions and technological prowess. The Ricardian model developed by Gomory and Baumol presents this analysis in a particularly useful way. In their multi-sector model, advanced countries compete for the most desirable industries. ${ }^{36}$ There are many possible free trade equilibrium, some more beneficial to a given country than others, so that gains to one country can come at the expense of a competitor. If country A gains an edge in a particular industry in which countries A and B are competing, A can obtain higher GDP while B ends up with lower GDP because it has to 
shift resources to lower valued sectors. In this model and others of its ilk, advanced countries compete with advanced countries in technology (and other societal attributes), but not in low cost labor. By contrast, trade between advanced countries and developing countries depends on differences in factor proportions and invariably benefits both countries. Countries with similar factor proportions have potential conflicting national interests in their industrial output of traded goods while countries with different factor proportions do not face such conflicts.

The North-South version of the trade model postulates that the advanced area (the North) has the skilled work force and R\&D capability to innovate new goods and services, while the less advanced area (the South) cannot compete in these areas (Krugman, 1979). As a result the North innovates new goods and trades them with the South, which produces older goods as it gains the technology do so. Once the two regions have access to the same technology, the lower wage South produces the good or service. Workers are higher paid in the North than in the South both because they are more skilled and because the North has a monopoly on the new products. More rapid technological advance increases wages in the North relative to wages in the South while more rapid diffusion of technology has the opposite effect. ${ }^{37}$ In these and other trade models, a country benefits when a trading partner or potential trading partner improves technology in a sector in which the country does not compete, but loses when another country improves its technology in a country's export sector. It is good for Alaska if El Salvador improves the technology of banana production, but bad for Nicaragua, since the improved technology will lower cost, increase banana production, and reduce the price of bananas on world markets. The South competes with the North for production of older products through low wages but is unable to compete in the newest technology.

The increased supply of scientific and engineering workers, including doctorate researchers 
and others able to advance scientific and technological knowledge in large developing countries, threatens to obsolesce this vision of trade between advanced and developing countries. It creates the possibility of human resource leapfrogging, in which large populous developing countries employ enough scientists and engineers to compete with the advanced countries in the high-tech vanguard sectors that innovate new products and processes and thus to threaten the North's monopoly in these sectors.

Three factors are necessary for human resource leapfrogging to shift the comparative advantage in high tech industries from the North to the South:

1. The Southern country must be sufficiently populous that it has large numbers of S\&E workers even though it deploys only a relatively small proportion of its work force in those fields. From the perspective of the US, there are only two countries with sufficiently large populations that they could develop larger S\&E work forces than the US: China and India;

2. Research and development productivity depends on the number of scientific and engineering workers applied to a problem. This seems plausible as a broad generalization. The firm or country that allocates, say, 2,000 engineers to a project is likely to beat the firm or country that allocates 1,000 engineers to the same project. But the way a country organizes its R\&D and the connection between research activities and business is also likely to affect productivity. The close ties between US universities and business and the well-developed system of competition for research funding arguably gives the US an advantage in turning research input into useful commercial output. Still, eventually numbers may dominate organization.

3. The South has the production competence to develop leading edge commercial products even though the bulk of the Southern work force is less skilled and the South lags behind the North in infra-structure. Again, this is most likely in highly populous countries that could recruit a 
substantial work force with any skill mix from its huge pool of workers and could develop the appropriate infrastructure in selected areas.

Under these circumstances, a populous developing country could compete in high-tech sectors and do what the North-South trade models have assumed the South could not do: compete effectively in R\&D intensive high tech industries. Even if the developing country had somewhat lower quality scientists and engineers or lacked some infrastructure that gave its laboratories lower productivity than those in advanced countries, it would have a cost advantage in R\&D in terms of lower wages for scientists and engineers, and would be able to employ less costly production labor to produce the relevant commercial products. The promise by Cisco to move its contract manufacturers to China as it developed research facilities in China presumably reflects more than the request of Chinese leaders, per the Chambers quote in endnote 26, but also the potentially lower cost of producing in China.

Loss of comparative advantage in the high-tech sector to a low wage competitor can substantially harm an advanced country. The advanced country would have to shift resources to less desirable sectors, where productivity growth through learning is likely to be smaller. Wages and living standards would remain high in the advanced country because of its skilled work force and infrastructure. But the monopoly rents from new products or innovations would shift from the advanced country to the poorer country. The magnitude of the loss would depend in part on the number of persons working in the advanced sector, and their next best alternatives. If the low wage country were to use its scientists and engineers to take a global lead in space exploration, there would be little impact on the economy of the advanced country. The first human on Mars would speak Chinese or Hindi rather than English. Students interested in space exploration might flock to the low wage country to learn from the new scientific leaders. US universities might 
contract or close their space science departments, but the adverse economic effects would be limited to that field.

Consider, by contrast, what would happen if the low wage country deployed its scientists and engineers to take a global lead in sectors with sizeable employment and significant throughput to the rest of the economy. In this case, the economic losses to the advanced country could be substantial. They would be larger than those that might occur if the advanced country lost its technological advantage to an equally advanced competitor because wages would have to fall more to make another sector competitive with the low wage competitor. ${ }^{38}$ In the extremum, if the only reason workers in the North were paid more than those in the South was that the North had a monopoly in innovating new products, the South would effectively become the North and the North would become the South, reversing their relative positions in wages. Technology would be a gold mine, and whichever country possessed the mine would be wealthier than the other.

Does the loss of technological advantage to a lower wage country necessarily harm an advanced country? Ron Jones and Roy Ruffin point out that under some circumstances the loss of technological advantage could benefit the advanced country. In their analysis, the advanced country has an absolute advantage in all sectors, and a comparative advantage in the high tech sector. It loses this comparative advantage so that it is completely wiped out as an exporter of high tech, so it becomes an exporter of the lower tech product. But it remains a high wage country and its living standards rise because the low wage country produces so much of the high tech good at such low prices that the terms of trade improve for the advanced country with the shift in comparative advantage. The US does better by producing apparel than by producing airplanes. This scenario seems more of a theoretical curiosum than a realistic representation of the current economic world. It occurs only if the advanced country has a large absolute advantage in the low 
technology product, which becomes its new export product, as well as in the high technology product; and that the large populous country has a work force (presumably measured in effective skill units) that is "much" larger than that of the advanced country; ${ }^{39}$ and does not give the high tech export sector any of the special features (greater rates of learning and productivity advance or economies of scale; with high wage jobs) that makes that sector particularly desirable. Loss of technological superiority in a particular sector to a low wage competitor might generate benefits for US consumers, but loss of technological superiority overall is likely to be disastrous for US workers and firms.

Looking at the technological edge that the US (and other advanced countries) have relative to developing countries from a different perspective, Donald Davis and David Weinstein argue that the flow of immigrants and foreign capital into the US reduces US well-being. With more workers and capital the US expands the production of the high tech goods in which the country has a comparative advantage, which drives down the price of those goods, and thus the earnings of native workers and capital. In this model, if foreign born workers remain overseas working with older or less productive technology, they are weaker competitors for American workers and firms. The implication is that the US could benefit from lower immigration and capital flows. My human resource leapfrogging analysis differs from the Davis and Weinstein analysis by making technological superiority endogenous to the supply of scientists and engineers, rather than an exogenous given. My analysis posits that immigrant scientists and engineers improve US technological competence and thus extend the North's lead in technology, although their supply does reduce the earnings or opportunities for American scientists and engineers. The human resource leapfrog model further assumes that the US technological superiority erodes as the foreign countries build up their science and engineering labor supplies, and as multinational firms 
locate where those supplies are cost effective. From the perspective of US workers, it is better for US workers to have immigrants use the newest technology in the US rather than having them develop or use it overseas, where wages and labor standards are lower.

\section{Real concerns or paranoia: the title question}

So, to what extent, if at all, does globalization of the scientific/engineering workforce threaten US economic leadership?

While the increase in S\&E workers in China, India, and other low wage countries, as well as in Europe and Japan, is too recent to provide a definitive answer to the title question, several indicators suggest that the answer is: yes, this form of globalization threatens, for better or worse, US technological and economic leadership.

The first indicator is that major high tech firms are locating new $\mathrm{R}$ and $\mathrm{D}$ facilities in China and India. This is not a matter of developing products for the Chinese or Indian markets with little expectation that the technology will be used for products in advanced countries. Instead, these facilities will produce advances that will lead to production in those countries for the global market. Microsoft's Advanced Technology Center, which opened in Beijing in 2003, is expected to help the company maintain its lead in technology and to develop and test new products. ${ }^{40}$

A second indicator is the off-shoring of some forms of skilled work. If educated workers in low wage countries can do similar tasks as educated workers in advanced countries, firms will try to offshore that work to the lower wage locale. While the US government does not measure the number of jobs off-shored, business consultants and business leaders indicate that the number is non-negligible and growing (see Hira and Hira, 2005). Some experts estimate that on the order of $10 \%-15 \%$ of employment in the US is potentially off-shorable (Bardhan and Kroll, 2003). For diverse reasons, India has been the main locale for the off-shoring of high level activity, but 
eventually China will also attract jobs in these areas as well. Advising companies how to offshore is itself a growing industry, with management consultants telling firms that they can gain as much as $40 \%$ more in profits from selected activities.

Third, indices of technological prowess show a huge improvement in the technological capability of China, in particular. Between 1993 and 2003, China closed part of the gap between it and the US and Japan in the Technological Standing Index that the Technology and Policy Assessment Unit at Georgia Tech has developed for the NSF (see Exhibit 7). ${ }^{41}$ In 1993 China received a 20.7 measure, whereas it was at 49.3. Consistent with this, the Georgia Tech group found that China was fourth in the world, after the USA, Japan and Germany, in publications in four emerging technologies in 1999; while the Nanotechnology Research Institute of Japan reported in 2004 that China was third and close behind Japan in publications and patents in this area. ${ }^{42}$ In terms of R and D spending on nano, China is fourth after the US, Japan, and the EU taken as a whole, although monetary comparisons are difficult given differences in prices and potential effectiveness of research facilities.

Finally, data on production and exports of high tech products shows that the improved capability of China in high technology has begun to show up in production and sales on the global market. From 1989 to 2001 the US maintained a 31\% share of world production in high tech industries, as the US economy outperformed the EU and Japan in these areas. But the US market share of exports fell from $24 \%$ to $17 \%$. The big gainer in the world production and exports was China. Between 1989 and 2001 the ratio of China's high tech output to the US's high tech output rose from $7.1 \%$ to $27.3 \%$. ${ }^{43}$ The share of electronics, machinery, and transport equipment in China's exports increased from $18.1 \%$ in 1994 to $42.9 \%$ in 2003, with the export shares of office and data processing equipment (including computers and components) rising the greatest percentage points. In the first quarter of 2005, the Chinese Ministry of Commerce reported 84 billion US dollars of foreign trade of high-tech products, up 26.2 percent over the same period last year. $^{44}$ 
In sum, research and technological activity and production are moving where the people are, even when they are located in the low wage "South". It is moving to China because China is graduating huge numbers of scientists and engineers and to India, as well, though more slowly.

\section{Proposition 4: Adjustment Problems and Policies for a New Era}

As the number of scientists and engineers working in foreign countries continues to increase, the US's comparative advantage in generating scientific and engineering knowledge and in the high-tech sectors and products associated with that knowledge will decline. This will be good for the world, as the spread of modern technologies to more economies will raise incomes in low income countries. Increased numbers of scientists and engineers will stimulate the growth of scientific and technical knowledge and the rate of technological advance, expanding the global production possibility frontier. The US will benefit from the greater advance of new knowledge and the production of new goods and development of new processes and the reduced costs of products from innovations and products developed elsewhere.

But the US will also face economic difficulties as its technological superiority erodes. What is good for the world is not inevitably good for the US. The group facing the biggest danger from the loss of America's technological edge are workers whose living standards depend critically on America's technological superiority. The decline in monopoly rents from being the lead country will make it harder for the US to raise wages and benefits to workers. The big winners from the spread of technology will be workers in developing countries, and the firms that employ them, including many US multinational corporations. In the long term, the spread of knowledge and technology around the world will almost certainly outweigh the loss of US hegemony in science and technology, but the transition period is likely to be lengthy and difficult more formidable than that associated with the recovery of Europe and Japan after World War II. The more similar the production technologies and composition of output in lower wage countries becomes to that of the US, the greater will be the downward pressures on US wages.

To minimize the costs of adjustment, the US will have to consider new policies in the labor market to distribute the national product more equitably and new policies in the market for R\&D 
and technology to build on existing strengths that will maintain scientific and technical leadership in some sectors and to remain close to the frontier in other areas. The country will also have to find ways to take scientific and technological advances from other countries and turn them into commercial products rapidly.

In the scientific and engineering job market, continued growth in the supplies of highly talented young people will stretch out the transition period and maintain the US as a center of scientific and technological excellence, albeit a less dominant center. The country could do this in several ways. It could continue to encourage large numbers of foreign students and SE immigrants to study and work in the country, at the cost of depressing incentives for domestic supply. If it does this, it ought to think about policies to encourage these students and immigrants to obtain permanent residence and citizenship quickly, to reduce the danger that they might return to their origin country and develop industrial activities that compete with those in the US. At the same time, the country could seek to increase domestic supplies without discouraging foreign students and immigrant, by giving more lucrative graduate research fellowships (which go to US students or residents only) and improving opportunities to do independent research early in a career, which is likely to increase US supplies more than those from foreign countries. From 1999 to 2005 NSF increased the value of its Graduate Research Fellowship Award from \$15,000 to $\$ 30,000$. The number of applicants nearly doubled as well, indicating a high elasticity of supply to the awards. But the number of awards has not changed much since the early days of the programs, so that in the 2000s approximately 1/3rd as many NSF Fellowships were granted per S\&E baccalaureate than in the 1950s-1970s (Freeman, Chang, Chiang). An increase in the number of awards at the new value of stipends could substantially increase the supply of citizens choosing S\&E studies.

On the demand side, the main tool that the US government has to affect S\&E intensive activity is the nation's government spending on R and D. Some economists might view any policy to direct that spending toward creating technological advantage in particular sectors as having the flavor of an industrial policy (as Japan did with its MITI activity, which means the government 
tries to pick industrial winners or protect losers. But a policy for research and development in new technologies is different than a policy of tariffs or subsidies. As long as the government is the main source of support for basic research directly through grants or indirectly through subsidization of universities, its expenditures already help set the technology and thus economy of the future. The doubling of NIH research spending spurred the life sciences, where increased knowledge will be more beneficial to biotechnical firms and the health industries than to most others. The National Nano-tech Initiative will spur engineering and physical sciences, which has the potential to benefit different sectors of the economy. On the other hand, a shift in R and D from areas likely to benefit the civilian economy toward military goals is likely to weaken US technological superiority in normal economic activity.

In adjusting to the globalization of science and engineering and the diminishment of US comparative advantage in high tech sectors, the US has some weaknesses. The country's social insurance system is not well-developed for helping workers cope with a potentially long period of transition. The country has the lowest safety net for workers and the most expensive employmentlinked health insurance system among advanced countries. It has done a relatively poor job in educating lower skill persons and ... you know the litany. But the country also has some great strengths for absorbing the loss of technological superiority in at least some sectors. The high mobility of the US work force should make some adjustments more palatable than if Americans were less willing to move location or change their occupation or industry. American scientists and engineers collaborate regularly with scientists and engineers in other countries. American universities are more closely linked to business and the economy than those in other countries. This should enable US higher education to continue its role in producing knowledge spillovers to industries in local areas, through spin-offs or other forms of knowledge transfer.

If the country maintains or improves its efficiency in moving knowledge from university labs to commercial products, the US comparative advantage in high technology sectors will be maintained longer than would otherwise be the case. Speaking with a Harvard physicist, whose most readily commercializable work was done collaboratively with overseas scientist and 
engineers, I commented, "ah, so you are helping them catch up with us", to which I received the reply, "no, they are helping us keep ahead of them". The reason was that the US side of the collaboration found it easier to deal with industry and to attract venture capital and business entrepreneurship. Empirically, US firms spend more on R and D relative to GDP than do EU firms and contribute more to university research programs. While there are dangers with businessuniversity linkages, about which Derek Bok has warned us, these links can help preserve leadership innovation and high tech even as the US share of world $\mathrm{PhD}$ researchers falls. 


\section{Bibliography}

American Institute of Physics, Statistical Research Center. 2003. Survey of Enrollments and Degrees, AIP Pub. Number R-151.39 (August). As Reported by Patrick J. Mulvey and Starr Nicholson. (http://www.aip.org/statistics/trends/reports/ed.pdf)

Arrow, Kenneth J. and William M. Capron. 1959. "Dynamic Shortages and Price Rises: The Engineer-Scientist Case," Quarterly Journal of Economics (73)2:292-308.

Bardhan, Ashok D. and Cynthia Kroll. 2003. "The New Wave of Outsourcing," Fisher Center Resaerch Reports, Paper 1103. (University of CA, Berkeley: Fisher Center for Real Estate and Urban Economics).

Blank, David M. and George J. Stigler. 1957. The Demand and Supply of Scientific Personnel. (NY: NBER).

Bok, Derek Universities in the Marketplace :Universities in the Marketplace:(Princeton, 2004)

Borjas, G. 2003 "The Labor Demand Curve Is Downward Sloping: Re-examining the Impact of Immigration on the Labor Market" Quarterly Journal of Economics (November) pp 1335-1374.

Brezis, Elise S., Paul R. Krugman, Daniel Tsiddon. "Leapfrogging in International Competition: A Theory of Cycles in National Technological Leadership," The American Economic Review 83(5)(December): 1211-1219.

Chang, Tanwin, Hanley Chiang, Richard B. Freeman, and Jason Abaluck. 2004. "How Do Stipends Affect the Supply of PhD Scientists and Engineers?" with Tanwin Chang, Hanley Chiang, and Jason Abaluck. NBER SEWP Report, conference presentation for the NSF/NIH/CGS Graduate Support Workshop, June 17-18, AAAS, DC.

Coe, D.T., E. Helpman, A.W. Hoffmaister. 1997. "North-South R\&D Spillovers," The Economic Journal, 107(44): 134-149.

Commission on Engineering and Technical Systems. 1986. Engineering Infrastructure Diagramming and Modeling.

Connolly, Michelle. 2003. "The Dual Nature of Trade: Measuring Its Impact on Imitation and Growth," Journal of Development Economics, 72(1): pp 31-55.

Connolly, Michelle, and Diego Valderrama. 2004. "North-South Technological Diffusion and Dynamic Gains from Trade," Federal Reserve Bank of San Francisco Working Paper 2004-24. (http://www.frbsf.org/publications/economics/papers/2004/wp04-24bk.pdf).

Davis, Donald R. and David E. Weinstein. 2002. "Technological Superiority and the Losses from Migration," NBER WP \# 8971 (May). 
Davis, Geoff. 2004. Sigma Xi National Postdoctoral Survey, November 11.

Finn, Michael G. 2003. "Stay Rates of Foreign Doctorate Recipients from U.S. Universities, 2001," Division of Science Resources Studies, National Science Foundation.

Freeman, Richard B. 1971. The Market for College Trained Manpower. Harvard Univ. Press.

Freeman, Richard B. 1976. "A Cobweb Model of the Supply and Starting Salary of New Engineers," Industrial Labor Relations Review January.

Freeman, Richard B. 1975. "Supply and Salary Adjustments to the Changing Science Manpower Market: Physics, 1948-1975," American Economic Review 65(1): 27-39 (March 1975).

Freeman, Richard B., Tanwin Chang and Hanley Chiang. 2005. "Recent Progress in S\&E Developments". Presented at the NBER SEWP Conference, Diversifying the Science and Engineering Workforce: Women, Underrepresented Minorities, and their S\&E Careers, January 14-15, http://www.nber.org/ sewp/events/2005.01.14/Agenda-1-14-05-WEB.htm

Freeman, Richard B., Emily Jin and Chia-Yu Shen. 2004. "Where Do New US-Trained Science-Engineering PhDs Come From?" NBER WP \# 10554 (June).

Goldman, Erica and Eliot Marshall, "NIH Grantees: Where Have All the Young Ones Gone?" Science Vol 298 (October 4, 2002).

Gomory, Ralph E. and William J. Baumol. 2000. Global Trade and Conflicting National Interests. (Cambridge: MIT).

Hicks, Diana. 2004. "Global Research Competition Affects U.S. Output," School of Public Policy, Georgia Institute of Technology, Atlanta (November 1). (C:\_dh/work $\backslash$ New Folder/higher ed book chap.doc)

Hira, Ron and Anil Hira. 2005. Outsourcing America: What's Behind Our National Crisis and How We Can Reclaim American Jobs (NY: AMACOM, American Management Association).

Jones, Ronald W. "Immigration vs. Outsourcing: Effects on Labor Markets," University of Rochester. (http://www.aueb.gr/deos/papers/GeorgakopoulosVolume_Hmerida_Papers_Jones.pdf)

Jones, Ronald W. and Roy J. Ruffin. 2005. “Can a Country Gain by Technology Loss?”

(http://gemini.econ.umd.edu/cgi-bin/conference/download.cgi?db_name=mwie2005\&paper_id=48)

Kirby, Kate and Roman Czujko. 1993. "The Physics Job Market: Bleak for Young Physicists," Physics Today, December, p 22. http://www.physicstoday.org/pt/vol-54/iss-4/p36.html

Krugman, Paul. 1979. "A Model of Innovation, Technology Transfer, and the World Distribution of Income,” The Journal of Political Economy Vol 87: 2 (April) pp 253-266.

MIT Technology Review. 2005. Briefcase (March).

National Academy of Science. 2000. Enhancing the Postdoctoral Experience for Scientists and Engineers.

National Science Foundation. 2004. Science and Engineering Indicators, 2004 (Washington, DC: USGPO). 
NSF SESTAT data system

NSF, Survey of Earned Doctorates (Washington DC:USGPO)

National Science Foundation. Survey of Graduate Students and Postdoctorates in Science and Engineering (GSS) 2002, (Washington, DC: USGPO).

National Science Foundation, Division of Science Resource Statistics. 2004. Science and Engineering Degrees by Race/Ethnicity of Recipients: 1992-2001, NSF 04-318. Project Officers, Susan T. Hill and Jean M. Johnson (Arlington, VA).

National Science Foundation. Characteristics of Doctoral Scientists and Engineers in the United States.

National Science Foundation, Division of Science Resource Statistics. 2005. Graduate Students and Postdoctorates in Science and Engineering: Fall 2002, NSF 05-310. Project Officers, Julia D. Oliver and Emilda B. Rivers (Arlington, VA).

National Science Foundation. "Undergraduate enrollment in engineering and engineering technology programs."

OECD. Education Statistics.

People's Daily. 2002. "China May Have More PhDs then the US in 2010". Http://peopledaily.com.cn/20021021_105393.htm

Porter, Alan L. and Scott Cunningham. 1995. "Whither Nanotechnology? A bibliometric study, Foresight Institute, Foresight Update 21 (June 1). http://www.foresight.org/Updates/Update21/Update21.4.html

Porter, Alan L., J. David Roessner, Xiao-Yin Jin and Nil C. Newman. 2002. "Measuring National 'Emerging Technology' Capabilities," Science and Public Policy Vol 20:3 (June).

Porter, Alan, David Roessner, Nils Newman, Alisa Kongthon, Xiao-Yin Jin. 2004. "Review and Revision of High Tech Indicators 2003: Final Report to the Science Indicators Unit," Science Resources Studies Division, National Science Foundation under Contract D020024 (February).

Regets. Mark. July 19, 2004. Presentation at the National Academy of Sciences, meeting on International Graduate Students and Postdocs, July 19, 2004 - July 20, 2004

Ruffin, Roy J. and Ronald W. Jones. 2004. "International Technology Transfer: Who Gains and Who Loses?" University of Rochester.

(http://www.wallis.rochester.edu/jones04/Ruffin-Jones_Technology_Transfer.pdf)

Shanghai Jiao Tong University, Institute of Higher Education. 2004. "Academic Ranking of World Universities - 2004," (http://ed.sjtu.edu.cn/rank/2004/2004Main.htm)

Song. Weiguo and Zhaohui Xuan (2004). "Preliminarv Analysis of China's Doctor Education," OECD Careers of Doctorates Workshop, September 2004.

The Economist Intelligence Unit. 2004. "Scattering the Seeds of Invention: The Globalisation of Research and Development," The Economist Intelligence Unit, The Economist (September). 
UNESCO. "Global Education Data Base"

(http://esdb.cdie.org/cgi-bin2/broker.exe?_program=gedprogs.ged_theme_une.sas\&_service=default )

U.S. Census Bureau, US Dept of Commerce, 2001. Current Population Reports 2000.

U.S. Census Bureau, US Dept of Commerce, 2005. Current Population Reports 2004.

U.S, Census Bureau, US Dept of Commerce. CPS IPUMS Data 1990.

U.S. Census Bureau, US Dept of Commerce. CPS IPUMS Data 2000.

U.S. Census Bureau, Statistical Abstract, 2004.

U.S. Census Bureau, Statistical Abstract, 1953.

Weinstein, Eric. "How and Why Government, Universities, and Industry Create Domestic Labor Shortages of Scientists and High-Tech Workers,"

(http://www.nber.org/ p peat/PapersFolder/Papers/SG/NSF.html)

Xinhua.net, 2004. "Multinational Corporations Establish 600 R\&D Centers in China. August 23. 
EXHIBIT 1: Ratio of \# S\&E PhDs from Foreign Universities to \# from US Universities

\begin{tabular}{lccccc} 
(Ratio of PhDs in each year) & $\mathbf{1 9 7 5}$ & $\mathbf{1 9 8 9}$ & $\mathbf{2 0 0 1}$ & $\mathbf{2 0 0 3}^{\mathbf{a}}$ & $\mathbf{2 0 1 0}^{\mathbf{a}}$ \\
\cline { 2 - 6 } Asia major nations & 0.22 & 0.48 & 0.96 & & \\
China & na & 0.05 & 0.32 & 0.49 & 1.26 \\
Japan & 0.11 & 0.16 & 0.29 & & \\
EU major (Fr, Germ, UK) & 0.64 & 0.84 & 1.07 & & \\
All EU & 0.93 & 1.22 & 1.54 & $1.62^{\mathrm{c}}$ & $1.92^{\mathrm{c}}$ \\
Chinese 'diaspora' vs. US & & & $0.72^{\mathrm{b}}$ & & \\
'stayers' (estimate) & & & & &
\end{tabular}

a For 2003 and 2010, ratios calculated using US doctorates at 2001 production level.

b 'diaspora' includes estimates of Chinese doctoral graduates from UK, Japan, and US (with temporary visas). US 'stayers' include US citizens and permanent residents.

${ }^{c}$ EU data extrapolated from earlier years.

Sources: NSF Science and Engineering Indicators 2004, and primary sources referenced therein; Weiguo and Zhaohui, National Research Center for S\&T Development (China) - private communication. 
EXHIBIT 2: Trend in Foreign-born Share of S\&E Employment

\begin{tabular}{lllc} 
& $\mathbf{1 9 9 0}$ & $\mathbf{2 0 0 0}$ & $\mathbf{2 0 0 4}$ \\
\cline { 2 - 4 } Bachelors & $11 \%$ & $17 \%$ & $17 \%$ \\
Masters & $19 \%$ & $29 \%$ & $32 \%$ \\
All PhD & $24 \%$ & $38 \%$ & $37 \%$ \\
PhDs $<45$ & $27 \%$ & $52 \%$ & - \\
Post-Doc & $49 \%$ & $57 \%$ & --
\end{tabular}

Source: 1990 and 2000 bachelor's, masters, $\mathrm{PhD}$ and $\mathrm{PhDs}$ less than 45 years of age, tabulated from Census of Population, IPUMS data; Post-Docs from NSF.

2004 figures tabulated from US Bureau of Census, Current Population Survey, MORG Files.

Post-Doc, NSF, http://www.nsf.gov/sbe/srs/seind04/c2/fig02-26.xls, where the figures refer to temporary residents rather than to foreign born 
EXHIBIT 3: Income in Thousands of Dollars and \% Change in Income, 1990-2000

\begin{tabular}{lccc} 
& $\mathbf{1 9 9 0}$ & $\mathbf{2 0 0 0}$ & \% Change \\
\cline { 2 - 4 } $\mathrm{PhD}$ & & & \\
Engineering & $\$ 64.6$ & 91.1 & 41.0 \\
Mathematics & 58.3 & 86.6 & 48.5 \\
Natural Science & 56.3 & 73.0 & 29.7 \\
Social Science & 54.2 & 74.6 & 37.6 \\
$\quad$ Life Science & 45.6 & 62.7 & 37.5 \\
MD & 98.8 & 156.4 & 58.3 \\
Lawyer & 76.9 & 114.7 & 49.2 \\
Managers , college + 2 years & 61.3 & 84.9 & 38.5 \\
College Grads, 4 years only & 30.8 & 46.9 & 52.2
\end{tabular}

Source: Tabulations from US Census of Population, IPUMS Data, 1990, 2000. 
EXHIBIT 4: Ratio of Number of Postdocs / Number of Tenured Faculty in Life Sciences

\begin{tabular}{lccc} 
Discipline & $\mathbf{1 9 8 7}$ & $\mathbf{1 9 9 9}$ & \%ostdocs / Tenured \\
\cline { 2 - 4 } & \multicolumn{2}{c}{ Pog } \\
Life Sciences & 0.54 & 0.77 & $43 \%$ \\
Physical Sciences & & & $-5 \%$ \\
$\quad$ Mathematics & 0.20 & 0.19 & $45 \%$ \\
Engineering & 0.11 & 0.16 &
\end{tabular}

Source: National Academy of Science, Enhancing the Postdoctoral Experience for Scientists and Engineers 2000, table B-14. 
EXHIBIT 5: Younger Scientists Don't Get NIH Grants

Share of NIH Grants

$<35$

$>45$

Relative Odds of Getting NIH, by age (ratio of shares of NIH grants to shares of PhDs)

$<35$

$>45$

Younger/Older

\begin{tabular}{cc}
$\mathbf{1 9 8 0}$ & $\mathbf{2 0 0 1}$ \\
\hline $23 \%$ & $4 \%$ \\
$22 \%$ & $60 \%$
\end{tabular}

0.30

0.52

1.07

2.33

Source:

NIH: Erica Goldman and Eliot Marshall, "NIH Grantees: Where Have All the Young Ones Gone?" Science Vol 298 (October 4, 2002).

NSF: Characteristics of Doctoral Scientists and Engineers in the United States. 
EXHIBIT 6: First Year Enrollments in Engineering Oscillate With Market Conditions, 1946-2001

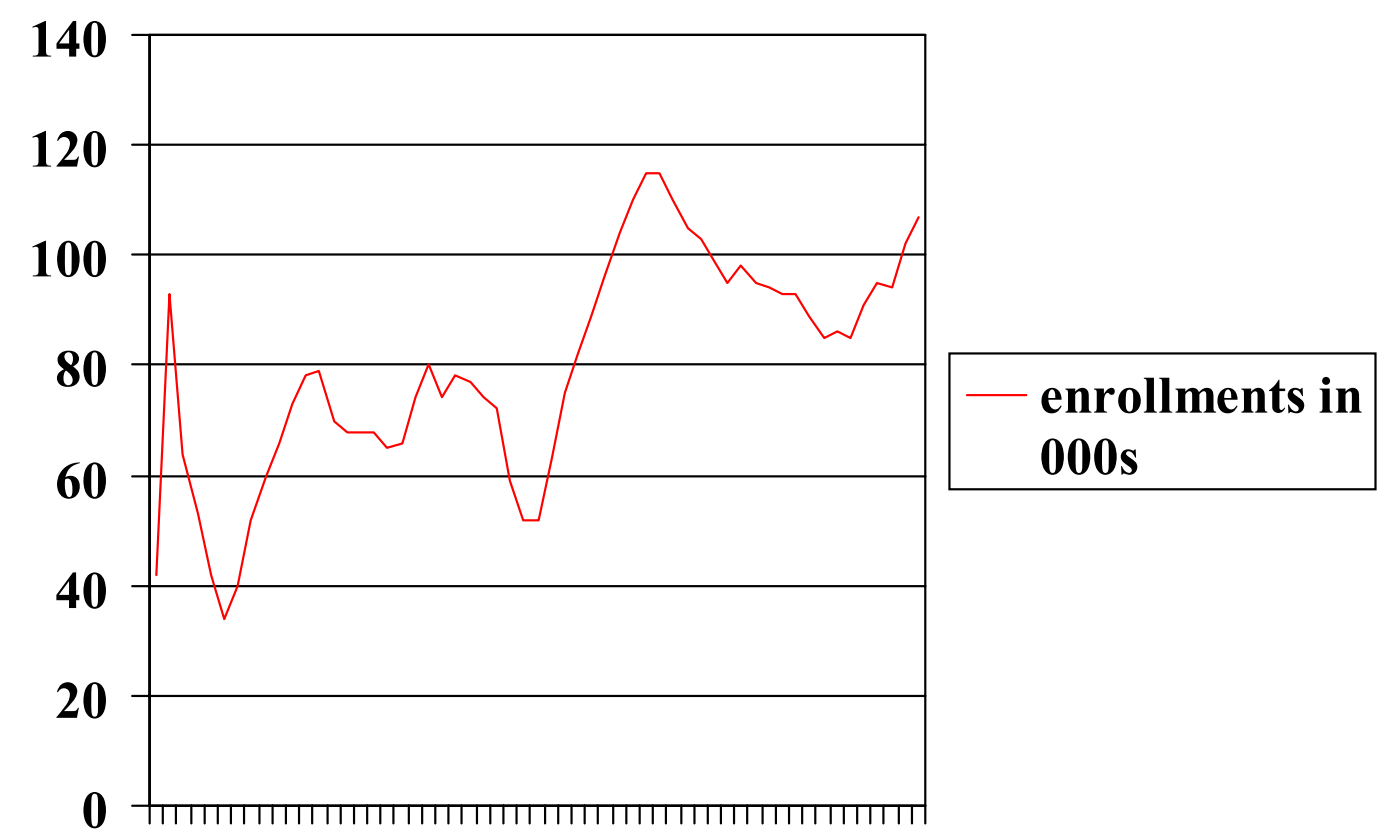

Source: Engineering Infrastructure Diagramming and Modeling (1986)

Commission on Engineering and Technical Systems;

National Science Foundation, Undergraduate enrollment in engineering and engineering technology programs 
Exhibit 7: Technological Standing Index, US, Japan, China, 1993-2003

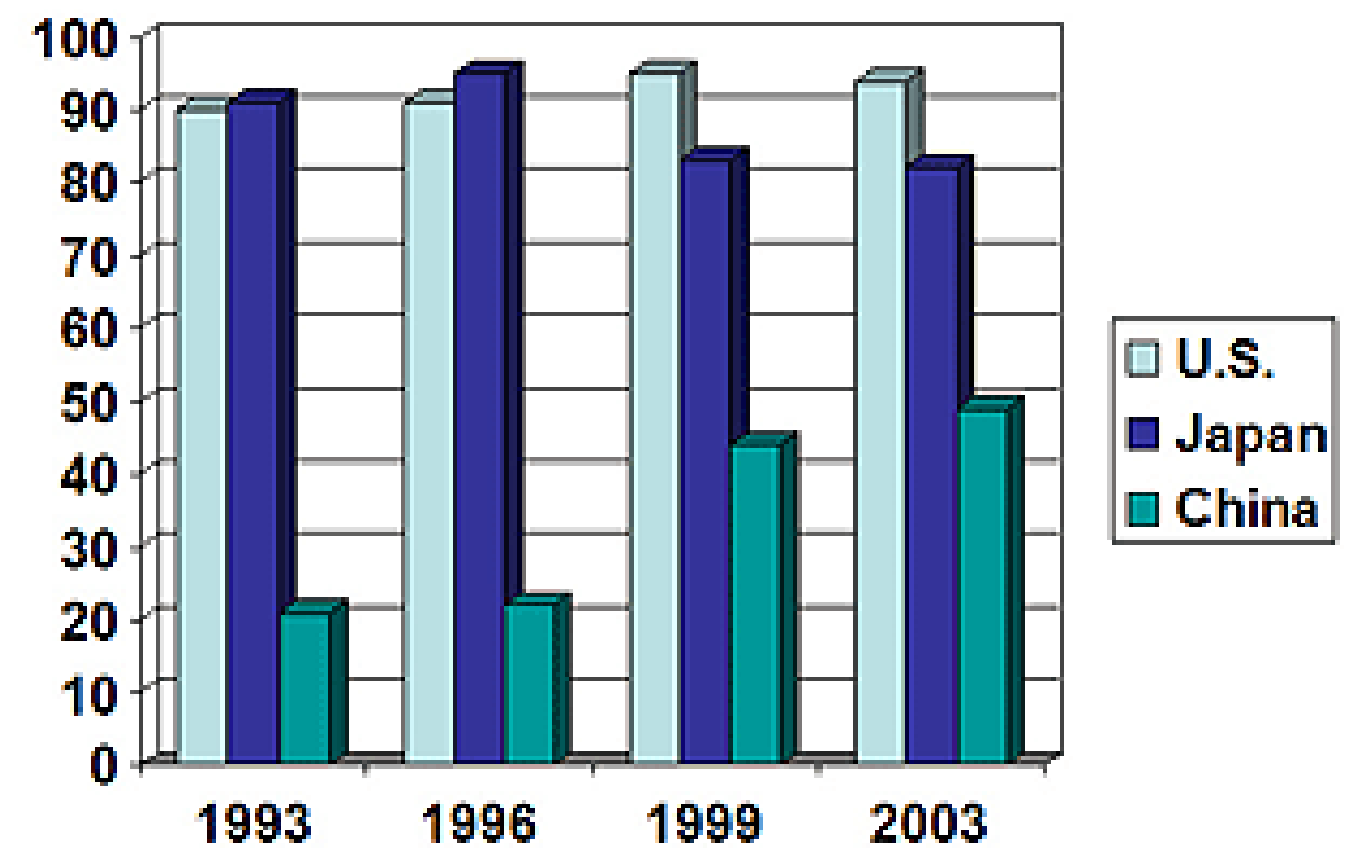

Source: Georgia Tech Technology Policy and Assessment Center, http://gtresearchnews.gatech.edu/newsrelease/techexports.htm 
1. A substantial proportion of whom are immigrants: Physics 32\%; Physio/Med 31\%; Economics, $31 \%$; Chemistry $26 \%$

2. This is according to the rating by Shanghai Jiao Tong University's Institute of Higher Education (http://ed.sjtu.edu.cn/rank/2004/2004Main.htm)

3. NSF, Science and Engineering Indicators, 2004, chapter 6. David Roessner, Alan L. Porter, Nils Newman, Xiao-Yin Jin . "A comparison of recent assessments of the high-tech competitiveness of nations" International Journal of Technology Management Vol. 23, No. 6, 2002pp. 536-557

4. Among factors that presumably affect production are: a high physical capital to labor ratio, public infrastructure, protection of property and rule of law, the education and skill of workers, incentives for work and supply responses to those incentives, openness to the employment of women, minorities, and immigration and an entrepreneurial culture.

5. NSF, Science and Engineering Indicators, 2004, appendix table 2-33 gives the degree data. OECD, Education Statistics gives enrollments. These data differ somewhat from the UNESCO tertiary enrollment figures.

6. The UNESCO data are from http://stats.uis.unesco.org/TableViewer/download.aspx, where I have filled in missing observations by taking the enrollments from the nearest year for which data are available. Tertiary level students are not always college students, so these data are imperfect. However, using data for college enrolments reported by individual countries, I obtain estimates of the US share comparable to the tertiary enrollment figures of UNESCO.

7.NSF, Science and Engineering Indicators, 2004, appendix table 2-33

8.R.B. Freeman, E. Jin, and C-Y. Shen. 2004. "Where Do New US-Trained Science-Engineering PhDs Come From?" Working Paper Series, Number 10544, NBER.

9.Data and taxonomies from the NSF Survey of Graduate Students and Postdoctorates in Science and Engineering (GSS) 2002, National Science Foundation. Life sciences includes biological sciences, agricultural sciences, and health fields; social sciences includes psychology; and physical sciences includes mathematics and earth sciences.

10. Subtracting the number of foreign-born doctorates graduating in the U.S. from the US total, the EU advantage increases to $60 \%$. Adding degrees granted in the US or other countries to Chinese citizens, while the Chinese earn $72 \%$ as many $\mathrm{PhDs}$ as are obtained by the U.S.-born.

11. AIP Survey of Enrollments and Degrees (As Reported by Patrick Mulvey, Statistical Research Center American Institute of Physics, www.aip.org/statistics

12.NSF, Science and Engineering Degreesby Race/Ethnicity of Recipients: 1992-2001, for degrees in 2001. NSF Graduate Students and Postdoctorates in Science and Engineering: Fall 2002, table 27, for enrollments in 2002, table 7. 
13. The 2000 data are from www.nsf.gov/sbe/srs/seind04/append/c2/at02-33.xls and cover the world. The 1991 data from www.nsf.gov/statistics/seind93/chap2/atab/at20193.xls, do not include several areas and countries, including South America, Russia, Middle East, Africa. I adjusted data for these omissions on the basis of the share of these countries in 2000 degrees.

14. Some S\&E workers, particularly in engineering, have less than college graduates, obtaining their skills from shorter training or working as technicians.

15.Michael G. Finn. 2003. "Stay rates of foreign doctorate recipients from U.S. universities, 2001," Division of Science Resources Studies, National Science Foundation.

16. The NSF created SESAT, a comprehensive and integrated system of information about the employment, educational, and demographic characteristics of scientists and engineers (S\&E) in the United States to provide data for policy analysis and general research. See http://srsstats.sbe.nsf.gov/docs/sestat3.html

17. I estimate that approximately $7 \%$ of US S\&E PhDs in 2000 Census were 1990s immigrants with foreign degrees. This implies that $1 / 3$ rd of the growth of foreign born $\mathrm{PhDs}$ in the period came from persons with overseas degrees.

18. Mark Regets, July 19, 2004. Estimates based on the NSF Survey of Doctorate Recipients 2001 and the NSF Survey of Graduate Students and Postdocs 2001; Geoff Davis, Sigma Xi National Postdoctoral Survey, November 11, 2004.

19.2004 Science and Engineering Indicators, Appendix Table 5-24, National Science Foundation. Available on line at http://www.nsf.gov/sbe/srs/seind02/append/c5/at05-24.xls

20. William J. Broad, "US is losing its dominance in the Sciences," NY Times, May 3, 2004 http://www.mindfully.org/Technology/2004/US-Losing-Dominance3may04.htm; "China Increases Share of Global Scientific Publications" http://www.nature.com/news/2004/040906/full/431116b.html.

21. NSF, Science and Engineering Indicators 2004, chapter 5

22. Michael Heylin, "Science is Becoming Truly Worldwide" Chemical and Engineering News, June 14, 2004 http://pubs.acs.org/cen/science/8224/pdf/8224sci2.pdf, p 40

23.Zhou and Leydesdorff report that between 1993 and 2004 the US share of scientific papers dropped from $34.7 \%$ to $30.5 \%$ while China's share rose from $1.7 \%$ to $6.5 \%$. Ping Zhou and Loet Leydesdorff "The Emergence of China as a Leading Nation in Science" http://users.fmg.uva.nl/lleydesdorff/ChinaScience/

24. Derek Hill, "Latin America show rapid rise in S\&E articles" http://www.nsf.gov/sbe/srs/infbrief/nsf04336/nsf04336.pdf

25. Because the average number of authors per scientific paper more than doubled over the past two or three decades, and U.S. scientists increasingly co-authored papers with people from other 
countries, the U.S. share of papers might have fallen even if the U.S. share of S\&E resources had been constant.

26. Chambers said to his Chinese audience:"What we're trying to do is outline an entire strategy of becoming a Chinese company ...Our contract manufacturers, at my request, and candidly at the request of the leaders in your country, began to move our contract manufacturers here to China." IDG News Service 9/27/04, "Tech companies building bridges with China" http://www.itworld.com/Tech/2418/040927techchina/pfindex.html

27.The Economist Intelligence Unit 2004 Scattering the Seeds of Invention The Globalisation of Research and Development, Sept 2004 http://graphics.eiu.com/files/ad_pdfs/RnD_GLOBILISATION_WHITEPAPER.pdf

28. "Multinational Corporations Establish 600 R\&D Centers in China," Xinhua.net, August 23, 2004. Kathleen Walsh, Foreign High Tech R\&D in China, www.stimson.org/techtransfer/pdf/FrontMatter.pdf

29.Kate Kirby and Roman Czujko, December 1993 Physics Today, p 22 http://www.physicstoday.org/pt/vol-54/iss-4/p36.html

30. The Research Project Grant (R01) provides support for health-related research and development based on the mission of the NIH. See http:/grants.nih.gov/grants/funding/r01.htm

31. US Bureau of the Census Statistical Abstract, 2004, table 597 and US Statistical Abstract, 1953, table 224

32. John Steedman, President of the Institute of Electrical and Electronics Engineers, Inc. United States of America, the largest association of engineers, attributed the unmployment to offshoring of high-tech jobs. www.ieeeusa.org/communications/releases/2004/022604pr.html

33. John Sargent An Overview of Past and Projected Employment Changes in the Professional IT Occupations, http://www.cra.org/CRN/articles/may04/sargent.html

34. 1995 from NSF Science and Engineering Indicators, 2004, appendix table 2-30;2002 from NSF, Graduate Students and Postdoctorates in Science and Engineering: Fall 2002 (NSF 05-310) table 47. www.nsf.gov/statistics/nsf05310/pdf/tables.pdf

35.Philip Chen, Foreign Scientists at the National Institutes of Health, October 12, 2004, presentation to Committee on Policy Implications of International Graduate Students and Postdoctoral Scholars in US, cited in Committee Report, National Academies Press, 2005, p 1.

36. In the model, one country produces all the output in an industry. this is equivalent to increasing the number of industries which the country dominates.

37.Connolly and Valderrama argue that the excessive imitation through reverse engineering by developing countries will reduce the North's incentive to invest and thus world living standards. They view intellectual property rights protection in trade agreements as a way to solve this 
problem.

38. Gomory and Baumol simulate how the loss of technological superiority of one advanced country to another advanced country reduces national income in a two country model. My claim is that loss of technological superiority to a low wage country will have a greater adverseeffect on national income. In a world with multiple sectors and countries, the situation would be more complicated, since the losses could be displaced to other advanced or low wage countries.

39. The model fits in the line of "immiserizing growth" models in which a country that makes a technological advance or investment in an export sector suffers a loss of GDP because the increased output produces an acute deterioration in the terms of trade.

40. MIT Technology Review, Briefcase, March 2005, pp 25-30.

41. This indicator compares the technological competitiveness of 33 nations on the basis of a diverse set of statistics, ranging from numbers of patents to measures of national orientiation and infrastructure to a survey of expert opinions about technological capabilities. See Alan Porter, David Roessner, Nils Newman, Alisa Kongthon, Xiao-Yin Jin Review and Revision of High Tech Indicators 2003 Final Report to the Science Indicators Unit, Science Resources Studies Division, National Science Foundation under Contract D020024

February 2004

42. http:/www.nanoworld.jp/apnw/articles/2-24.php

43. NSF, Science Indicators, 2004, appendix table 6-1

44. http://news.xinhaunet.com/english/2005-04/11/content_2815390.htm 